\title{
Titae
}

30 (2016) 295-313

Ks. Dariusz Lipiec

Katolicki Uniwersytet Lubelski Jana Pawła II dlipiec@kul.pl

\section{PARAFIA MIEJSCEM WYCHOWANIA DO POKOJU}

The Parish as a Place for Believers' Upbringing TOWARD PEACE

Kościół został powołany do wychowania swoich członków do pokoju. Szczególną rolę w realizacji tego posłannictwa odgrywa parafia, ponieważ jest miejscem spotkania człowieka z Bogiem w słowie Bożym, sakramentach, modlitwie i miłości braterskiej. Wychowanie do pokoju w parafii dokonuje się poprzez budowanie jedności między wierzącymi, której pokój, wychowanie do pokoju, parafia, wychowanie $\mathrm{w}$ parafii, funkcja wychowawcza parafii zasadą jest miłość braterska. Dokonuje się ono także przez kształtowanie świadomości i odpowiedzialności za pokój, a także postaw sprzyjających budowaniu jedności i pokoju. W proces wychowania do pokoju odbywający się w parafii zaangażowani są zarówno duchowni, jak świeccy parafianie, przede wszystkim rodziny i członkowie zrzeszeń religijnych. 
The Church was given the task of guiding Her members in the ways of peace. The parish plays a special role in realizing this mission, since it is the place where the individual meets God in His word, in the Sacraments, in prayer, and in brotherly love. In the parish, education in the value of peace is implemented first by building unity between the believers on the basis of brotherly love. It is also achieved through the deepening of one's awareness of and personal responsibility for peace, as well as by fostering the attitudes that support the building of unity and peace. The process of instructing and guiding believers toward peace is carried out by both the clergy and the laity, especially through families and members of religious associations. peace, training for peace, the parish, the educational function of the parish

Sobór Watykański II naucza, że pokój jest owocem miłości i sprawiedliwości. By mógł on zaistnieć i być obecny w świecie, konieczne jest pielęgnowanie tych cnót w życiu indywidualnym i społecznym. Podtrzymywanie i rozwijanie miłości i sprawiedliwości nie jest rzeczą łatwą. Nie są one dziełem jedynie ludzkim, ale darami Bożymi, danymi człowiekowi jako zasada i pomoc w realizacji życia wspólnotowego. Pokój w relacjach międzyludzkich jest w istocie dziełem Chrystusa, który na krzyżu zwyciężył nienawiść i udzielił swoim uczniom ducha miłości (KDK 78). Kościół nie postrzega pokoju jako jedynie braku wojny czy równowagi politycznej, ale jako efekt wzajemnego zaufania i otwarcia się ludzi i społeczeństw wynikającego z miłości oraz woli współpracy, na zasadzie sprawiedliwości i solidarności. Nauczanie Kościoła wskazuje, że troska o pokój jest dziełem trudnym i wymagającym. Dążenie do niego przypomina 
niesienie krzyża i wiąże się doświadczeniami Chrystusa na drodze krzyżowej (zob. KDK 38).

Do budowania pokoju wezwani są wszyscy ludzie, w sposób szczególny powołany jest Kościół. Jego zadaniem jest głoszenie Dobrej Nowiny o pokoju danym przez Chrystusa oraz wspieranie wysiłków ludzi dążących do pokoju. Kościół został powołany do inicjowania oraz pomocy w budowaniu współpracy na arenie lokalnej i międzynarodowej. Jego zadaniem jest również wychowanie do pokoju, obejmujące przede wszystkim członków własnej wspólnoty. Pojęcie wychowania do pokoju, jakie dokonuje się w Kościele i przez Kościół, wykracza poza rozumienie tego procesu w naukach pedagogicznych. Wychowanie do pokoju wpisuje się w realizację funkcji wychowawczej Kościoła, której celem jest zbawienie człowieka. Pierwszym wychowawcą jest Bóg. Kościół natomiast realizuje swoją funkcję „na wzór troskliwego ojca względem swoich dzieci, [który - D.L.] przez odmianę serca, nowe życie, naw rócenie, głęboko wchodzi, a zarazem tworzy nowy obraz społeczeństwa"'. Wychowanie do pokoju realizowane Kościele i przez Kościół jest więc częścią jego działalności, zmierzającej do zbawienia człowieka, rozumianego w aspekcie doczesnym i eschatologicznym.

Zadanie wychowania do pokoju zostało powierzone całemu Kościołowi. Szczególne zadanie w procesie wychowawczym przypada jednak parafii, ponieważ na niej „spoczywa główny ciężar odpowiedzialności pastoralnej”2 . Jest ona bowiem „miejscem uprzywilejowanym i najbardziej stosowanym gromadzenia się ludu Bożego dla wzrostu wiary i rozwoju formacji religijnej, dla sprawowania Eucharystii [...] oraz modlitwy. Wspólnota parafialna jest pierwszą szkołą radosnej i uczciwej przyjaźni [...], jest pierwszym punktem skupiającym wspólnotowe i społeczne orientacje, jest ciągłym spotykaniem się z miłością nastawioną na ofiarę i na

1 Drożdż, Wychowawcza funkcja, 56.

2 Kamiński. Dziatalność zbawcza, 171. 
służbę” 'S Święty Jan Paweł II nauczał, że parafia ma „zadanie bezpośredniej i osobistej formacji katolików świeckich [...], wychowanie swoich członków w słuchaniu Słowa, w liturgicznym i osobistym dialogu z Bogiem, w braterskiej miłości, i przybliżaniu im w sposób bardziej bezpośredni i konkretny znaczenia kościelnej komunii misyjnej i odpowiedzialności" (ChL 61). Częścią tego procesu formacyjnego, jaki dokonuje się w parafii, jest wychowanie do pokoju.

\section{PRZEPowiadanie W PARAFiI}

A WYCHOWANIE DO POKOJU

Głoszenie słowa Bożego w parafii zmierza ku poznaniu i zjednoczeniu człowieka z Bogiem. Odbywa się ono na drodze wiary, będącej odpowiedzią człowieka na Objawienie Boże. Wiara chrześcijańska oznacza w pierwszej kolejności przyjęcie i akceptację treści Objawienia, a następnie zastosowanie jej w życiu człowieka. Przejawia się to między innymi przyjęciem zasad moralności zawartych w Piśmie Świętym oraz kierowanie się nimi w życiu indywidualnym i społecznym. Przepowiadanie słowa Bożego w parafii ma więc charakter wychowawczy, kształtuje bowiem świadomość chrześcijanina oraz jego postawy. Odbywa się ono głównie poprzez przepowiadanie homilijne i katechezę.

Przepowiadanie słowa Bożego w parafii prowadzi człowieka do poznania Boga i Jego miłości do człowieka. Jest to nauczanie o Bogu będącym dawcą pokoju. Papież Benedykt XVI nauczat, że „pokój jest darem Boga. Pokój jest bowiem cechą Bożego działania, która przejawia się zarówno w stworzeniu uporządkowanego i harmonijnego wszechświata, jak też w odkupieniu ludzkości, która potrzebowała wyprowadzenia z niewoli grzechu”́ Pokój jawi się zatem jako dar Boga

3 Kamiński. Dziatalność zbawcza, 180-181.

4 Benedykt XVI, „Orędzie na XL Światowy Dzień Pokoju (2007)”, 4. 
przejawiający się w harmonii świata stworzonego oraz w uporządkowaniu życia ludzkiego w wymiarze indywidualnym i wspólnotowym. W naturze świata stworzonego, będącego środowiskiem życia człowieka oraz w osobie ludzkiej, będącej jego elementem, zawarty jest pokój. Potrzeba pokoju wypływa z wnętrza człowieka jako potrzeba harmonii, stąd dąży on do uporządkowania świata, a zwłaszcza życia społeczności ludzkiej. Przejawami pragnienia pokoju w sercu człowieka jest dążenie do sprawiedliwości i solidarności, które postrzega on jako komponenty porządku i ładu społecznego.

Pokój, będący darem Boga, jest jednocześnie zadaniem dla człowiekas. Jak każdy dar Boży wymaga on odpowiedzi osoby ludzkiej. Odpowiedź ta polega nie tylko na uznaniu i przyjęciu daru pokoju, ale przede wszystkim na podjęciu współpracy z Bogiem - Dawcą pokoju ${ }^{6}$. Chodzi tu o kształtowanie w człowieku zdolności życia $\mathrm{z}$ innymi i budowania pokojowej wspólnoty. Jest to zadanie duszpasterstwa parafialnego oraz całej lokalnej wspólnoty wierzących, które formują wnętrze człowieka, a zwłaszcza jego poczucie sprawiedliwości i solidarności. Parafia jest również miejscem i podmiotem socjalizacji religijnej i społecznej, kształtującym postawy altruistyczne. Formacja do życia w pokoju we wspólnocie parafialnej daje podstawę do aktywnego zaangażowania na płaszczyźnie narodowej i międzynarodowej. Charakterystyczną cechą wychowania do pokoju w parafii jest odkrywanie Bożego planu wobec człowieka, którego On powołuje do współpracy ze sobą, a także wobec świata, będącego miejscem zaangażowania człowieka. Odkrycie Bożego pokoju zawartego w harmonii świata stworzonego i uznanie Bożego planu względem człowieka i świata owocuje wiernością wobec Stwórcy. Kierowanie się Bożą wolą i Jego zasadami nie prowadzi do ograniczenia wolności człowieka,

5 Jan Paweł II, „Orędzie na XXXVIII Światowy dzień Pokoju (2005)”, 4-5.

6 Benedykt XVI, „Orędzie na XXXIX Światowy Dzień Pokoju (2006)”, 4. 
ponieważ jest zakorzenione w prawie naturalnym, natomiast pozytywne wezwanie Kościoła do współpracy z Bogiem wynika $\mathrm{z}$ tego prawa.

Z badań naukowych wynika, że źródłem braku pokoju $\mathrm{w}$ świecie współczesnym są wielorakie zagrożenia dla człowieka, skutkujące osłabieniem jego poczucia bezpieczeństwa. Są to różnego rodzaju zagrożenia militarne, polityczne, ekonomiczne, prawne, psychospołeczne, publiczne, ekologiczne czy zagrożenie terroryzmem, które wymierzone są nie tylko w porządek społeczny, ale w osobę ludzką, jej byt i prawa ${ }^{7}$. W świetle współczesnych zagrożeń parafia jawi się jako miejsce promocji osoby ludzkiej oraz jej praw, a także jako podmiot wychowania do szacunku dla człowieka. Wychowanie do pokoju w parafii oznacza przede wszystkim wychowanie do szacunku dla godności osoby ludzkiej i promocję jej praw. Przedmiotem przepowiadania jest nie tylko prawda o Bogu, ale także prawda o czlowieku, stworzonym na Jego obraz i podobieństwo ${ }^{8}$. Znaczy to, że nikt nie może dysponować osobą ludzką według własnego upodobania, a tym bardziej wykorzystywać jej z naruszaniem jej praw. „Na poszanowaniu praw wszystkich ludzi bowiem buduje się pokój. Mając tę świadomość, Kościół broni podstawowych praw każdego człowieka. W szczególności domaga się poszanowania życia i wolności religijnej"”.

Treścią przepowiadania parafialnego jest całe Objawienie. Współcześnie w przepowiadaniu homilijnym i katechetycznym trzeba przeciwstawiać się redukcjonistycznym wizjom człowieka, obciążonym przez różnego rodzaju ideologie, uprzedzenia kulturowe lub interesy polityczne i ekonomiczne. Popychają one bowiem do przemocy, budząc nienawiść, przez co stają się zagrożeniem dla pokoju. Redukcjonistyczne spojrzenie na człowieka idzie nierzadko w parze z redukcjo-

\footnotetext{
7 Durda - Kopczewski, „Współczesne zagrożenia”, 21-27.

8 Por. Gacka, „Kościół w obronie”, 36-38.

9 Benedykt XVI, Orędzie na XL Światowy Dzień Pokoju (2007)”, 5.
} 
nistycznym pojmowaniem Boga, co prowadzi do inicjowania wojen w imię Boga. Zadaniem odpowiedzialnych za głoszenie słowa Bożego w parafii jest przekazanie pełnej prawdy o Bogu i człowieku oraz ukazywanie prawdziwej natury ludzkiej. Na wizji osoby ludzkiej zawartej w Objawieniu możliwe jest następnie głoszenie praw człowieka, takich jak: równość ludzi bez względu na płeć, pochodzenie czy status społeczny, dostęp do dóbr naturalnych i kultury ${ }^{10}$. Głoszenie prawdy o godności i naturze człowieka stworzonym przez Boga jest aktywnym przeciwstawianiem się mentalności i kulturze przeciwnej pokojowi ${ }^{11}$.

Wychowanie do pokoju, dokonujące się w parafii, zasadzające się na uznaniu prawdy o Bogu i człowieku, obejmuje kształtowanie świadomości o godności stworzenia, powołanego do istnienia przez Boga. Kształtowanie pokoju oparte na harmonii i równowadze $\mathrm{w}$ świecie stworzonym przez Boga dotyczy nie tylko „ekologii człowieka” przejawiającej się w trosce o jego osobę i prawa, lecz także „ekologii natury”. Człowiek jest częścią świata stworzonego, któremu - jako dziełu Bożemu - należny jest szacunek. „Oznacza to, że ludzkość, jeśli zależy jej na pokoju, powinna zwracać coraz większą uwagę na związki, jakie istnieją między ekologią naturalną, czyli poszanowaniem przyrody, a ekologią ludzką. Doświadczenie pokazuje, że każda postawa braku poszanowania środowiska szkodzi wspótżyciu ludzkiemu, i odwrotnie. Coraz wyraźniej jawi się nierozerwalny związek miedzy pokojem ze światem stworzonym i pokojem między ludźmi"12. Zagrożeniem dla pokoju jest nierówny dostęp do źródeł energii, wody pitnej i surowców. Wyścig do zasobów naturalnych powoduje napięcia $\mathrm{w}$ relacjach międzynarodowych, zahamowanie rozwoju gospodarczego i kulturalnego krajów, a w nich - znacznej części społeczeństwa ${ }^{13}$.

10 Por. Kraj, „Prawo naturalne a pokój”, 52-54.

11 Por. Borutka, „Wychowanie do poszanowania”, 106-117.

12 Benedykt XV, „Orędzie na XL Światowy Dzień Pokoju (2007)”, 6.

13 Benedykt XV, „Orędzie na XLII Światowy Dzień Pokoju (2009)”, 3-8. 
Wychowanie do pokoju w parafii obejmuje głoszenie prawdy o świecie, który jest dziełem Boga, i z tego powodu zasługuje na szacunek (CiV 48) ${ }^{14}$. Kształtowanie szacunku dla natury wiąże się przede wszystkim z troską o przyrodę ożywioną i nieożywioną w otoczeniu parafian. Jest ona bowiem dobrem wspólnym danym mieszkańcom społeczności lokalnej. Konieczne jest więc kształtowanie przekonań i postaw zmierzających do troski o całe stworzenie, będące dobrem wspólnym ludzkości.

Kształtowanie świadomości i postaw proekologicznych wiąże się z koniecznością głoszenia nauki społecznej Kościoła. Zasady w niej sformułowane: zasada dobra wspólnego, sprawiedliwości, solidarności i pomocniczości, mają zastosowanie zarówno w życiu wspólnot lokalnych, których parafianie są aktywnymi uczestnikami, jak i społeczności narodowych i międzynarodowych. Szczególny obowiązek krzewienia katolickiej nauki społecznej spoczywa na katechezie, gdzie jej zasady są przekazywane i wyjaśniane. Jednak cała wspólnota parafialna jest odpowiedzialna za formację świata, zwłaszcza poprzez dawanie świadectwa życia chrześcijańskiego, ukazującego szacunek dla natury. Degradacja natury pociąga za sobą degradację człowieka i relacji międzyludzkich, co nieuchronnie prowadzi do konfliktów ${ }^{15}$.

\section{Liturgia I MODLITWA W PARAFII \\ A WYCHOWANIE DO POKOJU}

Wiara parafian prowadzi do uczestnictwa w liturgii. Liturgia zakłada wiarę jej uczestników, a także utwierdza ją i daje jej wzrost. Prawdy wiary przedstawiane są w liturgii w kontekście Osoby Chrystusa, poprzez proklamowanie tekstów biblijnych, dzięki czemu zostają pogłębiane i umacniane

14 Por. Jaromi, „Ekologia pokoju”, 67-74.

15 Benedykt XVI, „Orędzie na XLIII Światowy Dzień Pokoju (2010)”, 4-8. 
więzi parafian z Nim. Prawdy wiary i zasady moralności są przyjmowane nie jako wiedza abstrakcyjna, ale jako uznane i własne, odnoszone do własnej egzystencji.

Liturgia, chociaż odnosi człowieka do Boga w wymiarze wertykalnym, ma także wymiar horyzontalny. Czynności liturgiczne sprzyjają rozwijaniu wspólnoty wierzących z Bogiem, ich indywidualnemu rozwojowi duchowemu oraz wspólnoty między nimi. Wspólnota liturgiczna, będąca swego rodzaju objawieniem wspólnoty parafialnej, jest przede wszystkim dziełem Boga, który gromadzi wierzących, oraz dziełem samych wiernych, okazujących Mu posłuszeństwo. Otwierają się oni na Boga oraz na siebie nawzajem. Nawiązująca się w liturgii parafialnej komunikacja międzyosobowa z Bogiem i ludźmi powinna być kontynuowana po jej zakończeniu. Liturgia jawi się zatem jako punkt kulminacyjny i manifestacja życia wspólnoty parafialnej, jak również jako jej źródło. Aby liturgia zajmowała właściwe miejsce w świadomości i życiu parafian konieczna jest formacja liturgiczna, polegająca na pogłębianiu wiedzy o liturgii oraz na przygotowaniu do czynnego uczestnictwa w niej, a także do przekładania jej na życie codzienne ${ }^{16}$.

Szczytem życia parafii jest Eucharystia. Z niej bierze początek życie duchowe poszczególnych parafian i całej wspólnoty lokalnej, i do niej ono prowadzi. Jest ona zasadą jedności wierzących z Bogiem i między sobą. Jawi się też ona jako zasada życia parafialnego i całej działalności wychowawczej parafii. Jest ona źródłem braterstwa parafian, opartego na miłości chrześcijańskiej, będącej źródłem współpracy i pokoju.

Wychowanie do pokoju w kontekście celebrowania Eucharystii i uczestnictwa w niej odbywa się w dwojaki sposób. Następuje ono poprzez udział w celebracji Mszy Swiętej i adoracji eucharystycznej oraz poprzez formację do uczestnictwa w liturgii. Uczestnictwo w celebracji Eucharystii, a zwłaszcza Komunia Święta, oznacza zjednoczenie z Bogiem

16 Por. Kamiński, Duszpasterstwo w spoteczeństwie, 154-161. 
i wspólnotą. Wiąże się ona z otwarciem na Chrystusa i Jego oddziaływanie na wnętrze człowieka. Podczas zjednoczenia eucharystycznego następuje uświęcenie człowieka i upodobnienie do Chrystusa przebywającego w jego wnętrzu. Bóg w Komunii Świętej formuje człowieka na swoje podobieństwo, czyniąc go w pełniejszy sposób swoim dzieckiem i obdarzając swoimi cechami. W ten sposób chrześcijanin otrzymuje dar Bożej miłości i pokoju. Bóg udziela swoich darów, jednak ich przyjęcie jest uzależnione od stopnia otwarcia człowieka i gotowości współpracy z Bogiem. Oznacza to, że Bóg w takim stopniu może uformować w człowieku miłość i pokój, w jakim on na to pozwoli. W takim samym stopniu człowiek stanie gotowy do współpracy z Bogiem w przekazywaniu pokoju innym i czynienia zeń paradygmatu życia wspólnotowego.

Komunia Swięta oznacza także zjednoczenie z tymi, którzy łączą się z Chrystusem. Otwarcie na Boga i Jego działanie wiąże się z otwarciem w pierwszej kolejności na uczestników liturgii, a następnie na innych ludzi ${ }^{17}$. Przekazanie sobie znaku pokoju podczas celebracji mszalnej, poprzedzające Komunię sakramentalną, nie jest jedynie gestem symbolicznym, lecz realnym wyrażeniem jedności i przekazaniem pokoju pochodzącego od Chrystusa. Następujące zjednoczenie z Chrystusem obecnym w Eucharystii jest także zjednoczeniem $z$ braćmi. Chociaż ma ono inną naturę niż zjednoczenie z Bogiem, jest ono zjednoczeniem realnym. Nie jest możliwe zjednoczenie z Bogiem w Komunii z jednoczesnym zamknięciem się na braci, tak jak nie jest możliwe pełne otwarcie się na wspólnotę bez jednoczesnego zjednoczenia eucharystycznego z Chrystusem.

Bóg jednoczący się ludźmi w Eucharystii jest sprawcą jedności, miłości i pokoju miedzy nimi. Jest On jednocześnie nauczycielem pokoju, ponieważ obdarowany nim człowiek odczuwa jego otwarty na innych i zobowiązujący się

17 Por. Tarnowski, Wychowanie do pokoju, 74-76. 
do dzielenia charakter. Obdarowany pokojem chrześcijanin odwzajemnia go wobec Boga i dzieli się nim z innymi. W Eucharystii Bóg kształtuje pokój w człowieku, a także wychowuje go do dzielenia się nim z innymi. Ukazując człowiekowi wartość pokoju, Bóg wskazuje jednocześnie na moralne zobowiązanie przekazywania go innym. W ten sposób uczestnicy życia społecznego otrzymują, przez zaangażowanie wierzących, Boży pokój. Zadaniem parafian jest szerzenie tak otrzymanego pokoju przede wszystkim we własnej wspólnocie lokalnej, a następnie na wyższych szczeblach życia społecznego.

W dziele wychowania do pokoju w parafii znaczącą rolę odgrywa sakrament pokuty i pojednania ${ }^{18}$. Określany on bywa sakramentem Bożego miłosierdzia względem człowieka, ponieważ przywraca utraconą przez grzech jedność między Ojcem a dzieckiem. Grzech, zwłaszcza ciężki, jest zerwaniem łączności człowieka z Bogiem; jest także wprowadzeniem stanu braku pokoju w tych relacjach oraz zaprowadzeniem takiego stanu w duszy człowieka. Sakrament pokuty przezwycięża grzech człowieka, a przez to ponownie wprowadza pokój w jego relację z Bogiem, z innymi ludźmi oraz wprowadza jego duszę w stan pokoju. Często również grzech wprowadza człowieka w stan niezgody z samym sobą, który zostaje przezwyciężony w sakramencie pojednania.

Grzech jest źródłem braku jedności i pokoju przede wszystkim w środowisku życia: we wspólnocie rodzinnej, parafialnej i lokalnej. Sakrament pokuty jawi się więc jako sakrament odzyskiwania jedności i pokoju nie tylko między człowiekiem a Bogiem, lecz także w relacjach z najbliższymi. Doświadczenie miłosierdzia owocuje jego przekazaniem innym. Miłosierdzie jest bowiem darem Bożym, który dany człowiekowi jest darem zobowiązującym ${ }^{19}$. To zobowiązanie ma charakter przede wszystkim wewnętrzny. Człowiek nim

Por. Drożdż, Wychowawcza funkcja, 149-151.

19 Benedykt XVI, „Orędzie na Światowy XLVI Dzień Pokoju (2013)”, 8. 
obdarowany pragnie dzielić go z innymi, aby oni także mogli rozpocząć nowe życie w miłości i pokoju. Zobowiązanie to ma także charakter zewnętrzny: miłosierdzie, będące przejawem miłości, objęte jest przykazaniem miłości bliźniego ${ }^{20}$.

Rola sakramentu pokuty i pojednania w wychowaniu do pokoju nie ogranicza się do pojedynczych jego aktów, lecz wiąże się z systematycznym procesem kierownictwa duchowego. W tym procesie bowiem dokonuje się kształtowanie sumienia. Obowiązek kształtowania sumień wierzących spoczywa na Kościele, a w pierwszej kolejności na parafii. Zadaniem Kościoła jest takie formowanie sumienia, „aby nie poruszał nim każdy powiew nauki na skutek oszustwa ze strony ludzi [...], by - zwłaszcza w sprawach trudniejszych - mogło pewną drogą dojść do prawdy i w niej trwać" (VS 64). Takie kształtowanie sumienia dokonuje się również na drodze pozasakramentalnej. Duszpasterstwo parafialne dysponuje wieloma formami i metodami kształtowania sumienia, którymi są m.in. rozmowa duszpasterska, katecheza, praca $w$ grupach i inne. Wszystkie one formują sumienie, będąc środkami wychowania chrześcijanina do pokoju we wspólnocie parafialnej i społeczności ludzkiej.

Obok liturgii i kierownictwa duchowego w procesie wychowania do pokoju odbywającego się w parafii ważne miejsce zajmuje modlitwa. Wynika to z faktu, że pokój jest darem Boga, o który należy prosić ${ }^{21}$. Potrzeby modlitwy nie należy wynosić z przypuszczenia, jakoby Bóg nie był świadomy, że ludziom ten dar nie jest potrzebny lub że udziela go w zbyt małym stopniu. Modlitwa o pokój jest konieczna ze względu na fakt, iż ludzie zapominają o Bożym pochodzeniu pokoju i jego stan przypisują sobie i swojej działalności. Ponadto wielu ludzi jest przekonanych, że pokój jest dany ludzkości raz na zawsze i nie trzeba się o niego więcej troszczyć. Modlitwa o pokój przypomina chrześcijaninowi o Bożym pochodzeniu

20 Por. Tarnowski, Wychowanie do pokoju, 147-175.
21 Por. Tarnowski, Wychowanie do pokoju, 143-145. 
pokoju i o konieczności współpracy z jego Dawcą. Sprzyja ona otwarciu na ten dar, uwrażliwia sumienie na jego brak lub zagrożenie i czyni człowieka dyspozycyjnym względem Boga czyniącego pokój na ziemi.

Konieczne jest, aby parafia była miejscem modlitwy o pokój. Potrzebne są specjalne nabożeństwa okolicznościowe o pokój na świecie i w parafii. Należy organizować je systematycznie, ponieważ troska o pokój ma charakter permanentny, ale także wtedy, gdy pokój w jakichkolwiek regionach świata jest zagrożony. Wezwanie o pokój między ludźmi powinno towarzyszyć innym modlitwom zanoszonym podczas liturgii czy nabożeństw okolicznościowych.

\section{RealizaCja FunKCJi Pasterskiej W PARAFII A WYCHOWANIE DO POKOJU}

Działalność pastoralna w parafii zmierza do budowania wspólnoty wierzących. Parafia nie jest zbiorowiskiem luźno związanych ze sobą osób, lecz wspólnotą wiary, kultu i miłości braterskiej. Wspólnototwórczą wartość ma głoszenie i słuchanie słowa Bożego, które trafia do poszczególnych wierzących i przemienia ich w aktywnych słuchaczy Chrystusa oraz czyni z nich wspólnotę uczniów, razem zmierzających za głosem Nauczyciela. Taką funkcję pełnią również sakramenty i modlitwa w parafii, a zwłaszcza Eucharystia, będąca źródłem i szczytem życia wspólnotowego parafii. Cześć oddają Bogu nie tylko poszczególni parafianie, ale cała wspólnota wierzących, która w aktach kultu i wspólnej modlitwy doznaje umocnienia. Podobnie posługa miłości służy nie tylko umacnianiu poszczególnych parafian w wierze, nadziei i miłości, lecz także budowaniu wspólnoty opartej na chrześcijańskiej miłości, będącej zasadą życia społecznego.

Wysiłki pastoralne duszpasterzy oraz zaangażowanie laikatu skierowane są przede wszystkim ku budowaniu jedności (EG 228). Jest to realizacja nauczania Chrystusa, który modlił 
się o jedność uczniów (zob. J 17,21). Do budowania jedności zmierzają wszelkie wysiłki duszpasterskie prezbiterów w parafii, których posługa ma charakter służebny. Sposób sprawowania posługi, dobór środków i metod duszpasterskich, jak również charakter relacji z wiernymi mają służyć pogłębianiu ich jedności z Bogiem. Jednocześnie mają one służyć rozwijaniu więzi z Kościołem, przede wszystkim lokalnym, którym jest własna parafia. Przez nią dopiero rozwijają się ich więzi z diecezją i Kościołem powszechnym.

Zadaniem duszpasterstwa parafialnego jest także wychowanie wiernych do jedności ${ }^{22}$. Służy temu kształtowanie świadomości, że pogłębianie jedności z Bogiem, czyli budowanie wspólnoty w wymiarze wertykalnym, powinno iść w parze z pogłębianiem jedności z bliźnimi, czyli budowaniem wspólnoty w wymiarze horyzontalnym. Fakt budowania wspólnoty chrześcijańskiej na miłości braterskiej każe zwracać uwagę także na kierowanie się wierzących nie tylko ku tym, którzy znajdują się w pełnej jedności z Kościołem, ale także ku tym, którzy z powodu innego wyznania, wiary lub deklarowanego ateizmu znajdują się poza nim ${ }^{23}$.

Formacja parafian do braterstwa i jedności odgrywa zasadniczą rolę w wychowaniu do pokoju ${ }^{24}$. Papież Franciszek naucza, że braterstwo jest podstawą i drogą do pokoju ${ }^{25}$. Dotyczy to nie tylko wielkich społeczności, jakimi są społeczności narodowe i społeczność międzynarodowa, lecz także społeczności niewielkich, lokalnych, w których chrześcijanie w praktyce budują jedność opartą na solidarności, a przez to wprowadzają pokój w ich życie. Oznacza to, że formacja do jedności w parafii jest jednocześnie wychowaniem do pokoju, ponieważ bez niego jedność nie jest możliwa.

Zadaniem duszpasterzy parafialnych jest wspieranie wszystkich podmiotów, które podejmują wychowanie do poko-

22 Por. Borutka, „Wychowanie do poszanowania”, 118-121.

23 Por. Kondziela, Pokój w nauce Kościota, 49-57.

24 Franciszek, „Orędzie na XLVIII Światowy Dzień Pokoju (2015)”, 4-5.

25 Franciszek, „Orędzie na XLVII Światowy Dzień Pokoju (2014)”, 6. 
ju. Pierwszym i podstawowym z nich jest rodzina. „Żyjąc $\mathrm{w}$ «zdrowej» rodzinie, poznaje się niektóre podstawowe komponenty pokoju: sprawiedliwość i miłość pomiędzy braćmi i siostrami, władzę, jaką sprawują rodzice, pełne miłości posługiwanie najsłabszym członkom - małym, chorym albo starszym, wzajemna pomoc w życiowych potrzebach, gotowość do akceptacji drugiego człowieka i, gdy zachodzi taka potrzeba, do przebaczenia. Dlatego rodzina jest pierwszą i niezastąpioną wychowawczynią do życia w pokoju" ${ }^{26}$. Jako podstawowe zadanie parafii jawi się ochrona naturalnego charakteru rodziny oraz jej podstawowych praw ${ }^{27}$. Dotyczy ono zarówno duchownych, jak wszystkich parafian, zarówno na płaszczyźnie parafialnej, jak przez zaangażowanie na arenie lokalnej i krajowej. Bez zabezpieczenia jej charakteru i praw, rodzina nie może w całej rozciągłości odgrywać roli podstawowej komórki życia społecznego, w tym także skutecznie wychowywać do pokoju ${ }^{28}$. Zadaniem całego środowiska, w tym także parafii, jest wspieranie rodziców $\mathrm{w}$ procesie wychowawczym. Instytucjonalna pomoc ze strony duszpasterstwa oraz moralne wsparcie ze strony innych rodzin umacniają kondycję rodziny i umożliwiają większą skuteczność wysiłków wychowawczych.

Parafia określana jest nierzadko jako wspólnota wspólnot, co oznacza, że skupia ona w sobie inne, mniejsze wspólno-

26 „Wspólnota ludzka nie może obejść się bez posługi, jaką pełni rodzina. W jakim innym miejscu kształtująca się ludzka istota mogłaby lepiej poznać «smak» pokoju, jeśli nie w rodzinnym «gnieździe», które daje jej natura? Język, jakim posługuje się rodzina jest językiem pokoju, i z jego zasobów zawsze powinniśmy czerpać, aby nie zapoznać «mowy» pokoju”. Zob. Benedykt XVI, „Orędzie na XLI Światowy Dzień Pokoju (2008)”, 25.

27 Franciszek, „Orędzie na XLV Światowy Dzień Pokoju (2012)”, 5. „Kto [...] nawet nieświadomie działa na szkodę instytucji rodziny i ja osłabia naraża na szwank pokój całej wspólnoty narodowej i międzynarodowej, gdyż osłabia instytucję, która jest faktycznie główną szkołą pokoju”. Zob. Franciszek, „Orędzie na XLV Światowy Dzień Pokoju (2012)", 5. 
ty. Są nimi różnorakie zrzeszenia religijne: stowarzyszenia, ruchy i małe grupy religijne, które formują swoich członków według charyzmatu określonego przez ich założycieli. Podstawową wartością zrzeszeń religijnych jest ich zdolność do jednoczenia ludzi we wspólnoty oparte na braterskiej miłości. Są one miejscem wzrostu wiary chrześcijańskiej, a także kształtowania członków w wymiarze ludzkim, duchowym, intelektualnym i apostolskim. W nich dokonuje się także wychowanie do pokoju. W pierwszej kolejności jest to wychowanie do pokoju i jedności z członkami własnej grupy, a następnie otwarcie na budowanie jedności i pokoju w parafii i środowisku lokalnym, a przez nie z całym Kościołem oraz społecznością narodową i międzynarodową ${ }^{29}$.

Duszpasterstwo wspiera powstawanie i rozwój zrzeszeń religijnych na terenie parafii. Liderzy i członkowie stowarzyszeń, ruchów i małych grup religijnych traktowani są jako współpracownicy duchownych w budowaniu wspólnoty parafialnej oraz w realizacji posłannictwa parafii. Tym samym zaangażowani w zrzeszenia religijne w parafii są współpracownikami duszpasterzy w wychowaniu do jedności i pokoju.

\section{ZAKOŃCZENIE}

Z nauczania Kościoła wynika, ze parafia należy do podstawowych miejsc wychowania do pokoju. Do jej najważniejszych zadań należy formacja wierzących, mająca wymiar ludzki, doktrynalny, duchowy i apostolski. Kształtowanie wierzących, w tym także wychowanie do pokoju, dokonuje się poprzez głoszenie i słuchanie słowa Bożego, sakramenty i modlitwę oraz posługę miłości. Zadaniem duszpasterstwa jest kształtowanie świadomości i postaw propokojowych parafian. Wychowanie do pokoju, odbywające się w parafii, owocować ma najpierw w pokojowym współżyciu wspólno-

29 Benedykt XVI, „Orędzie na XLIV Światowy Dzień Pokoju (2011)”, 8. 
ty parafialnej i społeczności lokalnej. Wypracowane poglądy i postawy parafian przejawiają się jednak także w życiu na arenie ponadparafialnej: we wspólnocie narodowej, społeczności państwowej i ponadpaństwowej.

\section{BiBLIOGRAFIA}

Benedykt XVI, „Orędzie na XL Światowy Dzień Pokoju Osoba ludzka sercem pokoju (2007)", L'Osservatore Romano (wyd. pol.) 28/2 (2007) 4-8.

Benedykt XVI, „Orędzie na XLI Światowy Dzień Pokoju Rodzina wspólnota pokoju (2008)", L'Osservatore Romano (wyd. pol.) 29/1 (2008) 25-28.

Benedykt XVI, „Orędzie na XLII Światowy Dzień Pokoju Zwalczanie ubóstwa droga pokoju (2009)", L'Osservatore Romano (wyd. pol.) 30/1 (2009) 3-8.

Benedykt XVI, „Orędzie na XLIII Światowy Dzień Pokoju Jeśli chcesz krzewić pokój, strzeż dzieta stworzenia (2010)", L'Osservatore Romano (wyd. pol.) 31/1 (2010) 4-8.

Benedykt XVI, „Orędzie na XLIV Światowy Dzień Pokoju Wolność religijna droga do pokoju (2011)", L'Osservatore Romano (wyd. pol.) 32/1 (2011) 4-11.

Benedykt XVI, „Orędzie na XLV Światowy Dzień Pokoju Wychowanie mtodzieży do sprawiedliwości i pokoju (2012)", L'Osservatore Romano (wyd. pol.) 33/2 (2013) 4-8.

Benedykt XVI, „Orędzie na XLVI Światowy Dzień Pokoju Btogostawieni pokój czyniący (2013)", L'Osservatore Romano (wyd. pol.) 34/1 (2013) 4-8.

Benedykt XVI, „Orędzie na XXXIX Światowy Dzień Pokoju Pokój w prawdzie (2006)", L'Osservatore Romano (wyd. pol.) 27/2 (2006) 4-7.

Borutka T. - Żemła B., Chrześcijańskie wychowanie do pokoju (Kraków: Wydawnictwo Naukowe PAT 2000). 
Drożdż B., Wychowawcza funkcja Kościota w spoteczeństwie pluralistycznym. Studium pastoralne (Legnica: Wyższe Seminarium Duchowne 1997).

Durda A. - Kopczewski M., „Współczesne zagrożenia bezpieczeństwa", Państwo wobec wspótczesnych zagrożeń (red. M. Cupryjak - P. Nowak) (Szczecin: Uniwersytet Szczeciński 2014) 11-32. Franciszek, „Orędzie na XLVII Światowy Dzień Pokoju Braterstwo podstawa pokoju i droga do niego (2014)", L'Osservatore Romano (wyd. pol.) 35/1 (2014) 4-10.

Franciszek, „Orędzie na XLVIII Światowy Dzień Pokoju Już nie niewolnicy, lecz bracia (2015)", L'Osservatore Romano (wyd. pol.) 35/12 (2014) 4-8.

Gacka B., „Kościół w obronie godności osoby ludzkiej”, Osoba ludzka i pokój (red. J. Kamula) (Licheń: Centrum Formacji Misyjnej „Salvatoris Mater” 2007) 21-40.

Jan Paweł II, „Orędzie na XXXVIII Światowy dzień Pokoju Nie daj się zwyciężć ztu, ale zto dobrem zwyciężaj (2005)", L'Osservatore Romano (wyd. pol.) 26/2 (2005) 4-8.

Jan Paweł II, Encyklika „Veritatis splendor” (1993).

Jan Paweł II, Posynodalna adhortacja apostolska „Christifideles laici" (1988).

Jaromi S., „Ekologia pokoju - pokój ze światem stworzonym a pokój pomiędzy ludźmi”, Osoba ludzka i pokój (red.J. Kamula) (Licheń:

Centrum Formacji Misyjnej „Salvatoris Mater” 2007) 61-82. Kamiński R., Duszpasterstwo w spoteczeństwie pluralistycznym (Lublin: Atla 2 1997).

Kamiński R., Dziatalność zbawcza Kościota w teorii i praktyce pastoralnej (Lublin: Wydawnictwo KUL 2007).

Kondziela J., Pokój w nauce Kościota. Pius XII - Jan Pawet II (Lublin: RW KUL 1992).

Kraj T., „Prawo naturalne a pokój”, Osoba ludzka i pokój (red. J. Kamula) (Licheń: Centrum Formacji Misyjnej „Salvatoris Mater" 2007) 41-60.

Sobór Watykański II, Konstytucja duszpasterska o Kościele w świecie wspótczesnym „Gaudium et spes” (1965). 
Tarnowski J., Wychowanie do pokoju z Bogiem i ludźmi (Poznań: Księgarnia Sw. Wojciecha 1984).

Ks. Dariusz Lipiec, prezbiter diecezji siedleckiej, doktor habilitowany teologii pastoralnej, profesor KUL, pracownik Katedry Prakseologii Pastoralnej w Instytucie Teologii Pastoralnej i Katechetyki Katolickiego Uniwersytetu Lubelskiego Jana Pawła II, autor Duszpasterstwo niewidomych i stabowidzacych w Polsce. Studium teologicznopastoralne (Lublin: Wydawnictwo KUL 2011). 